\title{
Seroprevalance and Co-infection of Hepatotropic Viruses in Acute Viral Hepatitis Cases
}

\author{
Nasiruddin M. Shaikh, Tanmay K. Mehta* and Parul D. Shah \\ Department of Microbiology, Smt. N.H.L. Municipal Medical College, \\ Ahmedabad, Gujarat, India-380006 \\ *Corresponding author
}

\section{A B S T R A C T}

\begin{tabular}{|l|}
\hline K e y w or d s \\
Co-infection, HAV, \\
HEV, HBV, Acute \\
viral hepatitis.
\end{tabular}

Acute viral hepatitis (AVH) is a major public health problem and is an important cause of morbidity and mortality. The aim of the present study is to find seroprevalance and coinfection rate of hepatotropic viruses in suspected cases of acute viral hepatitis at a tertiary care hospital of western India. Samples of Acute viral Hepatitis cases were tested for hepatitis B surface antigen, anti-HAV IgM and anti-HEV IgM by the enzyme-linked immunosorbent assay from $1^{\text {st }}$ April 2014 to $31^{\text {st }}$ March 2015 at a tertiary care hospital in western India. HEV infection was found in $687(74.43 \%)$ cases, followed by HAV 226(24.48\%) cases and HBV 46 (4.98\%) cases. Infection with more than one virus was detected in $69(7.47 \%)$ cases, the most common being HAV and HEV co-infection in 44 $(4.76 \%)$ cases. Co-infection of hepatitis viruses is not infrequent and detected in many cases of AVH. Therefore, testing for all hepatotropic viruses' infection should be done in acute viral hepatitis cases regardless of route of transmission. The declined incidence of HEV infection with an evolving epidemiologic shift of HAV infection indicates the improvement in sanitary conditions.

\section{Introduction}

Acute viral hepatitis (AVH) is a major public health problem in India and other developing nations having inadequate sanitary conditions. Acute viral hepatitis (AVH) is a systemic infection affecting the liver predominantly. It is caused by six distinct types of viruses A, B, $\mathrm{C}, \mathrm{D}, \mathrm{E}$ and $\mathrm{G} .{ }^{[1]}$

HAV and HEV are an important cause of acute viral hepatitis and acute liver failure in India. The most common clinical consequence of infection with hepatitis A or E virus is acute hepatitis. A large majority of people with acute viral hepatitis recover spontaneously within a few weeks, without any residual consequences. However, in some persons, acute liver failure (ALF) may occur. Patients with ALF have a high case-fatality rate, in the absence of liver transplantation, which is either inaccessible or non-affordable for a large majority of Indian population. Infection with $\mathrm{HBV}, \mathrm{HCV}$, or HDV too may present as acute hepatitis.

However, these viruses have the potential to cause persistent infection in a subset of those infected. Such infection may be associated with ongoing liver damage, which may progress to liver cirrhosis or liver cancer, which can be life-threatening. India has 
"intermediate to high endemicity" for Hepatitis B surface antigen and an estimated 40 million chronic HBV infected people, constituting approximately $11 \%$ of the estimated global burden. ${ }^{[2]}$

Very few studies describing the pattern of hepatitis viruses in AVH are available from India. ${ }^{[3-7]}$ Therefore, this study was undertaken to determine the sero-prevalence and co-infection rate of hepatotropic viruses among suspected cases of AVH to plan appropriate management of cases as well as preventive strategies.

The main objectives of this study include to find out seroprevalance and co-infection rate of hepatotropic viruses in suspected cases of acute viral hepatitis (AVH) at a tertiary care hospital of western India.

\section{Materials and Methods}

A cross-sectional observational study was done from $1^{\text {st }}$ April 2014 to $31^{\text {st }}$ March 2015 at a tertiary care hospital in western India. Total 923 suspected cases of acute viral hepatitis $(\mathrm{AVH})$ patients were enrolled in the study.

An Acute Viral Hepatitis (AVH) case was defined as a person having an acute illness of less than 15 days duration with a discrete onset of any sign or symptom (e.g., fever, headache, malaise, anorexia, nausea, vomiting, diarrhea and abdominal pain) and either a) jaundice or b) elevated serum alanine aminotransferase (ALT) levels more than 100 IU/L documented at least twice at a 1-week interval without any history of pre-existing liver disease. ${ }^{[8]}$

Three ml of human blood sample irrespective of age and gender was collected from each patient. Serum was separated with centrifugation of each sample and stored at
$-20{ }^{\circ} \mathrm{C}$ until tested. Only aadequate amount of non-hemolysed, non-lipemic serum without precipitate or particulate matter was tested.

The serum samples were tested to detect HAV immunoglobulin $\mathrm{M}(\operatorname{IgM})$ against capsid protein for HAV infection, hepatitis B surface antigen (HBsAg) for HBV infection and HEV IgM for HEV infection. All analyses were performed using commercial kits based on the enzyme-linked immunosorbent assay (ELISA) as per the manufacturer's instructions which include blank, negative control, positive control and calibrator in dispensation scheme. Relevant clinical information was collected from the laboratory database and forms. Appropriate descriptive statistics (e.g. percentages etc.) was used to describe studied variables.

\section{Results and Discussion}

Total 923 serum samples from suspected cases of Acute Viral Hepatitis (AVH) were tested. Hepatitis $\mathrm{E}$ virus infection was found in $687(74.43 \%)$ cases, followed by HAV infection in 226(24.48\%) cases and HBV infection in $46(4.98 \%)$ cases (Table 1$)$.

Infection with more than one virus in same patient at a time could be detected in 69 $(7.47 \%)$ cases, the most common being HAV and HEV co-infection in $44(4.76 \%)$ cases. Co-infection of HBV with HAV or HEV or both was present in $25(2.70 \%)$ cases (Table 2).

Although cases were seen throughout the year, $86(9.31 \%)$ and $280(30.33 \%)$ of cases of HAV and HEV were seen from August to October that is monsoon seasons in this part of the country. HBV infection did not show any seasonal pattern (Table 3 ).

In age group 0-15 years HAV IgM positive cases were 184 (19.93\%), HAV and HEV 
IgM positive cases were 27 (2.95\%). In age group $>15$ years HEV IgM positive cases were 595 (64.46\%), HBs Antigen positive cases were 42 (4.55\%), HEV IgM and HBs antigen positive cases were $16(1.73 \%)$. In the same age group HEV IgM, HAV IgM and HBs antigen positive cases were 2(0.21\%) (Table 4).

In our study HEV infection (74.43\%) was the most common cause of acute viral hepatitis followed by HAV infection (24.48\%) and HBV infection (4.98\%). Several other studies on Acute viral hepatitis have reported varying prevalence of hepatotropic viruses infections: HAV (1.7-67\%), HBV (7.3-42\%) and HEV (16.3-66.3\%). ${ }^{[5-10]}$ Patients with acute viral hepatitis due to HAV also had high coinfection rate of $\mathrm{HEV}$ probably because of similar routes of transmission for hepatitis A and E viruses. ${ }^{[11]} \mathrm{HAV}$ and $\mathrm{HEV}$ infections are endemic in India and infections occur throughout the year, though peaks are seen in monsoon months from August to October. Since this is a hospital based data the true seasonal distribution in the community could not be assessed. Earlier studies have found either no seasonal peaks or a peak in summer and monsoon months of the year. ${ }^{[12-13]}$

We found decreased seroprevalance of HAV $(4.55 \%)$ induced AVH in adults compared to previous studies done in India $(8 \%) .{ }^{[14]}$ In children HAV infection is low (19.93\%) in present data compared to other studies (37.564\%). ${ }^{[15]}$ HEV seroprevalance in children $(9.96 \%)$ was lower than that reported by other studies (16.3-66.3\%). Several studies from different parts of India have reported a shift in the age of acquiring HAV infection has been seen from childhood to older age groups in India and globally; this shift is known as epidemiological shift. ${ }^{[15-16]}$ Our observations indicates improvement in living standards and hygiene of the Indian population.

Table.1 Sero-prevalence of HAV, HBV and HEV

\begin{tabular}{|c|c|c|c|c|c|c|}
\hline \multirow{2}{*}{$\begin{array}{c}\text { Total suspected cases of } \\
\text { AVH tested }\end{array}$} & \multicolumn{2}{|c|}{ HBs Antigen } & \multicolumn{2}{c|}{ HAV IgM Antibody } & \multicolumn{2}{c|}{ HEV IgM Antibody } \\
\cline { 2 - 7 } & Negative & Positive & Negative & Positive & Negative & Positive \\
\hline 923 & $877(95.01 \%)$ & $46(4.98 \%)$ & $697(75.51 \%)$ & $226(24.48 \%)$ & $236(25.56 \%)$ & $687(74.43 \%)$ \\
\hline
\end{tabular}

Table.2 Co-infection cases among HAV, HBV and HEV sero-positive cases

\begin{tabular}{|c|c|c|c|c|}
\hline $\begin{array}{c}\text { HAV IgM and HEV } \\
\text { IgM positive cases }\end{array}$ & $\begin{array}{c}\text { HBs Ag and HAV } \\
\text { IgM positive cases }\end{array}$ & $\begin{array}{c}\text { HBs Ag and HEV } \\
\text { IgM positive cases }\end{array}$ & $\begin{array}{c}\text { HBs Ag, HAV IgM and } \\
\text { HEV IgM positive cases }\end{array}$ & $\begin{array}{c}\text { Total Co- } \\
\text { infection cases }\end{array}$ \\
\hline $44(4.76 \%)$ & $3(0.32 \%)$ & $19(2.05 \%)$ & $3(0.32 \%)$ & $69(7.47 \%)$ \\
\hline
\end{tabular}

Table.3 Seasonal distribution among HAV, HBV and HEV sero-positive cases

\begin{tabular}{|c|c|c|c|c|c|c|c|c|}
\hline $\begin{array}{c}\text { Month } \\
\text { and Year }\end{array}$ & $\begin{array}{c}\text { Total suspected } \\
\text { cases of AVH } \\
\text { tested }\end{array}$ & $\begin{array}{c}\text { HBsAg } \\
\text { Positive }\end{array}$ & $\begin{array}{c}\text { HAV IgM } \\
\text { Positive }\end{array}$ & $\begin{array}{c}\text { HEV } \\
\text { IgM Positive }\end{array}$ & $\begin{array}{c}\text { HAV IgM and } \\
\text { HEV IgM } \\
\text { Positive }\end{array}$ & $\begin{array}{c}\text { HBsAg and } \\
\text { HAV IgM } \\
\text { Positive }\end{array}$ & $\begin{array}{c}\text { HBsAg and } \\
\text { HEV IgM } \\
\text { Positive }\end{array}$ & $\begin{array}{c}\text { HAV IgM, HEV } \\
\text { IgM and } \\
\text { HBsAg Positive }\end{array}$ \\
\hline Apr-14 & $38(4.11 \%)$ & $3(0.32 \%)$ & $8(0.86 \%)$ & $27(2.92 \%)$ & $0(0 \%)$ & $0(0 \%)$ & $1(0.1 \%)$ & $0(0 \%)$ \\
\hline May-14 & $36(3.90 \%)$ & $0(0 \%)$ & $9(0.97 \%)$ & $27(2.92 \%)$ & $1(0.1 \%)$ & $0(0 \%)$ & $0(0 \%)$ & $0(0 \%)$ \\
\hline Jun-14 & $76(8.23 \%)$ & $12(1.3 \%)$ & $11(1.19 \%)$ & $54(5.85 \%)$ & $0(0 \%)$ & $0(0 \%)$ & $5(0.54 \%)$ & $0(0 \%)$ \\
\hline Jul-14 & $132(14.30 \%)$ & $0(0 \%)$ & $27(2.92 \%)$ & $103(11.15 \%)$ & $5(0.54 \%)$ & $0(0 \%)$ & $0(0 \%)$ & $0(0 \%)$ \\
\hline Aug-14 & $79(8.55 \%)$ & $3(0.32 \%)$ & $20(2.1 \%)$ & $61(6.60 \%)$ & $5(0.54 \%)$ & $1(0.1 \%)$ & $2(0.21 \%)$ & $0(0 \%)$ \\
\hline Sep-14 & $158(17.11 \%)$ & $6(0.65 \%)$ & $38(4.11 \%)$ & $124(13.43 \%)$ & $9(0.97 \%)$ & $1(0.1 \%)$ & $2(0.21 \%)$ & $2(0.21 \%)$ \\
\hline Oct-14 & $118(12.78 \%)$ & $5(0.54 \%)$ & $28(3.03 \%)$ & $95(10.29 \%)$ & $6(0.65 \%)$ & $0(0 \%)$ & $5(0.54 \%)$ & $0(0 \%)$ \\
\hline Nov-14 & $73(7.90 \%)$ & $6(0.65 \%)$ & $22(2.38 \%)$ & $48(5.2 \%)$ & $2(0.21 \%)$ & $0(0 \%)$ & $3(0.32 \%)$ & $0(0 \%)$ \\
\hline Dec-14 & $49(5.30 \%)$ & $2(0.21 \%)$ & $15(1.62 \%)$ & $35(3.79 \%)$ & $4(0.43 \%)$ & $0(0 \%)$ & $0(0 \%)$ & $0(0 \%)$ \\
\hline Jan-15 & $74(8.01 \%)$ & $5(0.54 \%)$ & $23(2.49 \%)$ & $47(5.09 \%)$ & $5(0.54 \%)$ & $0(0 \%)$ & $0(0 \%)$ & $0(0 \%)$ \\
\hline Feb-15 & $54(5.85 \%)$ & $2(0.21 \%)$ & $15(1.62 \%)$ & $38(4.11 \%)$ & $3(0.32 \%)$ & $0(0 \%)$ & $0(0 \%)$ & $0(0 \%)$ \\
\hline Mar-15 & $36(3.90 \%)$ & $2(0.21 \%)$ & $10(1.08 \%)$ & $28(0.30 \%)$ & $4(0.43 \%)$ & $1(0.1 \%)$ & $1(0.1 \%)$ & $1(0.1 \%)$ \\
\hline
\end{tabular}


Table.4 Age distribution among HAV, HBV and HEV seropositive cases

\begin{tabular}{|c|c|c|}
\hline Name of Test(s) & Less than or equal to 15 years & More than 15 years \\
\hline HAV IgM positive & $184(19.93 \%)$ & $42(4.55 \%)$ \\
\hline HEV IgM positive & $92(9.96 \%)$ & $595(64.46 \%)$ \\
\hline HBs Ag positive & $4(0.43 \%)$ & $42(4.55 \%)$ \\
\hline HAV and HEV IgM positive & $27(2.95 \%)$ & $16(1.73 \%)$ \\
\hline HAV IgM and HBsAg positive & $3(0.32 \%)$ & $0(0 \%)$ \\
\hline HEV IgM and HBs Ag positive & $3(0.32 \%)$ & $16(1.73 \%)$ \\
\hline HEV, HAV IgM and HBsAg positive & $1(0.1 \%)$ & $2(0.21 \%)$ \\
\hline
\end{tabular}

Diagnosis of HEV is primarily based on detection of specific antibody. Anti-HEV IgM antibodies indicate recent infection, but they disappear rapidly. Anti-HEV IgG antibodies can be detected in up to $96 \%$ of acute infections during the first 4 weeks, and they disappear in at least $50 \%$ of patients by 3 months after the onset of acute disease. ${ }^{[17]}$

The duration of HEV antibody persistence after exposure has not been established. Recurrent acute HEV infections have been documented, suggesting that the HEV antibody does not persist on a long-term basis [18]. This could also explain the low prevalence of HEV IgM positive cases among our patients.

Other studies have found Hepatitis B as the second most important cause of $\mathrm{AVH}$, while we observed it as the third causative agent of AVH. It could not be determined whether these were co-infections or super-infections.

But, it is known that both co-infection and super-infection usually cause complications leading to high morbidity and mortality. ${ }^{[19]}$ Study done earlier at Lucknow, states that co-infection does not produce a more severe disease. ${ }^{[20]}$

HBV and HEV co-infection was found in $2.05 \%$ cases with. Other studies also noted a high rate of super infection with HEV in hepatitis B surface antigen carriers. ${ }^{[21,22]}$ Transmission of HEV occurs predominantly by the fecal-oral route. However, the parenteral route has also been implicated. ${ }^{[23]}$
HAV, HEV and HBV co-infections was also found in 3 cases in our study.

This study had a limitation of not studying epidemiological shift of HAV and HEV infections based on age specific immunoglobulin $\mathrm{G}(\mathrm{IgG})$ prevalence levels.

Another limitation here is that testing for $\mathrm{HCV}$ infection was not done for all acute viral hepatitis cases which are reported to have prevalence of $1.1-3.1 \%$ in children and 2.02$10.6 \%$ in adults in other studies.

The reduced seroprevalance of HEV infection with an epidemiologic shift of HAV infection indicate the improvement in living and hygienic standards of the Indian population.

Co-infection of HAV, HEV and HBV was not infrequent and detected in many cases of AVH. So Testing for all hepatotropic viruses e.g., HAV, HEV, HBV and HCV should be done in all acute viral hepatitis cases regardless of route of transmission.

Testing for all hepatotropic viruses' infection should be done in acute viral hepatitis cases regardless of route of transmission as coinfection of hepatitis viruses is not infrequent and detected in many cases of AVH.

\section{References}

Acharya, S.K., Batra Y, Hazari S, Choudhury V, Panda SK, Dattagupta S. Etiopathogenesis of acute hepatic failure: Eastern versus Western 
countries. J Gastroenterol Hepatol 2002; 17: S268-73.

Aggarwal, R., Krawczynski K. Hepatitis E: An overview and recent advances in clinical and laboratory research. $J$ Gastroenterol Hepatol, 2000; 15: 9-20.

Arora, N.K., Nanda SK, Gulati S, Ansari IH, Chawla MK, Gupta SD, et al., Acute viral hepatitis types E, A, and B singly and in combination in acute liver failure in children in north India. $J$ Med Virol 1996; 48: 215-21.

Batra, Y., Bhatkal B, Ojha B, Kaur K, Saraya A, Panda SK, et al., Vaccination against hepatitis A virus may not be required for schoolchildren in northern India: Results of a seroepidemiological survey. Bull World Health Organ 2002; 80: 728-31.

Bukh, J., Purcell RH, Miller RH. Importance of primer selection for the detection of hepatitis $\mathrm{C}$ virus RNA with the polymerase chain reaction assay. ProcNatlAcadSci U S A, 1992; 89: 18791.

Coursaget, P., Buisson Y, N'Gawara MN, Van Cuyck-Grande H, Roue R. Role of hepatitis $\mathrm{E}$ virus in sporadic cases of acute and fulminant hepatitis in an endemic area (Chad). Am J Trop Med Hyg. 1998; 58: 330-4.

Irshad, M., Hepatitis E virus: a global view of its seroepidemiology and transmission pattern. Trop Gastroenterol. 1997; 18: 45-9.

Irshad, M., Singh S, Ansari MA, Joshi YK. Viral hepatitis in India: A Report from Delhi. Glob J Health Sci 2010;2:96-103.

Kaur, R., Gur R, Berry N, Kar P. Etiology of endemic viral hepatitis in urban North India. Southeast Asian J Trop Med Public Health, 2002; 33: 845-8.

Ke, W.M., Tan D, Li JG, Izumi S, Shinji Y, Hotta $\mathrm{H}$, et al., Consecutive evaluation of immunoglobulin $\mathrm{M}$ and $\mathrm{G}$ antibodies against hepatitis $\mathrm{E}$ virus. $J$ Gastroenterol. 1996; 31: 818-22.

Kumar, A., Yachha SK, Poddar U, Singh U, Aggarwal R. Does co-infection with multiple viruses adversely influence the course and outcome of sporadic acute viral hepatitis in children? $J$ Gastroenterol Hepatol, 2006; 21: 15337.

Kumar, S., Ratho RK, Chawla YK, Chakraborti A. The incidence of sporadic viral hepatitis in North India: A preliminary study. Hepatobiliary Pancreat Dis Int, 2007; 6: 596-9.

Kunasol, P., Cooksley G, Chan VF, Isahak I, John J, Loleka S, et al., Hepatitis A virus: Declining seroprevalance in children and adolescents in Southeast Asia. Southeast Asian J Trop Med Public Health, 1998; 29: 255-62.

Mathur, P., Arora NK, Panda SK, Kapoor SK, Jailkhani BL, Irshad M. Seroepidemiology of hepatitis $\mathrm{E}$ virus (HEV) in urban and rural children of North India. Indian Pediatr., 2001; 38: 461-75.

Mathur, P., Arora NK. Epidemiological transition of hepatitis A in India: Issues for vaccination in developing countries. Indian J Med Res, 2008; 128: 699-704.

Parana, R., Cotrim HP, Cortey-Boennec ML, Trepo C, Lyra L. Prevalence of hepatitis $\mathrm{E}$ virus $\mathrm{IgG}$ antibodies in patients from a referral unit of liver diseases in Salvador, Bahia, Brazil. Am J Trop Med Hyg. 1997; 57: 60-1.

Poddar, U., Thapa BR, Prasad A, Singh K. Changing spectrum of sporadic acute viral hepatitis in Indian children. J Trop Pediatr., 2002; 48: 210-3.

Purcell, R.H., Emerson SU. Hepatitis E virus. In: Mandell GL, Bennett JE, Dolin R, eds. Principles and practice of infectious diseases. Philadelphia, PA: Churchill Livingstone; 2000; 345-57. 
Sheikh, A., Sugitnai M, Kinukawa N, Moriyama M, Arakawa Y, Komiyama $\mathrm{K}$, et al., Hepatitis $\mathrm{E}$ virus infection in fulminant hepatitis patients and an apparently healthy population in Bangladesh. Am J Trop Med Hyg. 2002; 66: 721-4.

Singh, J., Prakash C, Gupta RS, Bora D, Jain DC, Datta KK. Epidemiology of endemic viral hepatitis in an urban area of India: A retrospective community study in Alwar. Bull World Health Organ, 1997; 75: 463-8

Tandon, B.N., Gandhi BM, Joshi YK. Etiological spectrum of viral hepatitis and prevalence of markers of hepatitis $A$ and $B$ virus infection in north India. Bull World Health Organ, 1984; 62: 6773.

United States Centers for Disease Control and Prevention. 2012 National Notifiable Diseases and Conditions and Current case Definitions.

Viral Hepatitis- The Silent Disease Facts and Treatment Guidelines. National Centre for Disease Control and Directorate General of Health Service, Ministry of Health and Family Welfare Government of India.

\section{How to cite this article:}

Nasiruddin M. Shaikh, Tanmay K. Mehta and Parul D. Shah. 2017. Seroprevalance and Coinfection of Hepatotropic Viruses in Acute Viral Hepatitis Cases. Int.J.Curr.Microbiol.App.Sci. 6(9): 1304-1309. doi: https://doi.org/10.20546/ijcmas.2017.609.157 